\author{
TEM内その場観察による \\ ベータ型チタン合金の変形挙動解析 \\ 小野瀨 航平 ${ }^{1} \cdot$ 倉本 繁 ${ }^{2 *} \cdot$ 鈴木 $^{\text {拓哉 }}{ }^{3} \cdot$ Ya-Ling $\mathrm{CHANG}^{4}$ \\ 仲川 枝里 ${ }^{4} \cdot$ 大村 $^{\text {孝仁 }}{ }^{4,5} \cdot$ 岩本 $^{\text {知広 }}{ }^{2}$
}

Journal of The Japan Institute of Light Metals, Vol. 69, No. 5 (2019), 273-280
(c) 2019 The Japan Institute of Light Metals

\title{
Analysis of deformation behavior in beta titanium alloys using TEM in-situ observation
}

\author{
Kohei ONOSE ${ }^{1}$, Shigeru KURAMOTO ${ }^{2 *}$, Takuya SUZUKI ${ }^{3}$, Ya-Ling CHANG ${ }^{4}$ \\ Eri NAKAGAWA ${ }^{4}$, Takahito OHMURA ${ }^{4,5}$ and Chihiro IWAMOTO ${ }^{2}$
}

\begin{abstract}
Deformation behavior has been studied in a multifunctional beta titanium alloy, Gum Metal, using in-situ nanopillar-compression tests in transmission electron microscope in comparison with a conventional beta titanium alloy, beta III. In-situ observations for dislocation activity and phase transformation during compression test of solution treated samples have been performed in bright-field and diffraction modes. Distinct contrast of dislocations has not been observed during the tests in bright field mode, however subtle contrast change, which might be related to dislocation motion, has been observed in localized areas of the Gum Metal specimen. In the diffraction mode, pre-existing diffraction from omega phase decreased, and diffraction from alpha double prime phase increased with increase amount of plastic deformation. In addition, a pillar of Gum Metal with large length-to-thickness ratio showed a large amount of pseudoelastic deformation after unloading. These results have been discussed in relation to deformation mechanisms in these beta titanium alloys.
\end{abstract}

(Received November 22, 2018 Accepted February 8, 2019)

Keywords: titanium alloy; dislocation; martensitic transformation; in-situ observation; psuedoelasticity

\section{1. 緒言}

ゴムメタルは体心立方構造を持つ $\beta$ 型チタン合金であり, 基本的に $\mathrm{Ti}_{3}(\mathrm{Nb}, \mathrm{Ta}, \mathrm{V})+(\mathrm{Zr}, \mathrm{Hf})+\mathrm{O}$ と表される組成で，組成平 均の価電子数 $\mathrm{e} / \mathrm{a}$ が約 4.24, DV-Xaクラスター法による結合 次数 Bo が約 $2.87, \mathrm{Md}$ 值が約 $2.45 \mathrm{eV}$ の 3 つのパラメータを満 たす組成の合金である ${ }^{1), 2)}$ 。ゴムメタルは溶体化処理材でも 低ヤング率かつ高強度であるが, 強冷間加工を施すことに よって，さらに低ヤング率化，高強度化するとともに，超塑 性的特性，超弾性的特性，インバー特性，エリンバー特性と いった数々の特性を有するようになることが知られており, これらの特性はゴムメタルの特殊な塑性変形機構 ${ }^{3) \sim 5)}$ に起 因して発現するものと考えられている。ゴムメタルの塑性変 形機構については，理想強度自体が低下することと，転位運 動抑制により塑性変形が阻害されることによって，理想強度
レベルで断層を断続的に形成していく非転位型の塑性変形機 構が発現すると考えられてきた。一方で, ゴムメタルの塑性 変形は熱活性化過程に支配されているため, 非転位型ではな く一般的な金属と同様の転位機構により進行するという見解 も圧縮試験の結果から得られている。現時点では, 変形時の 転位の直接観察はほとんどされておらず変形機構の解明には 至っていない ${ }^{6), 7) 。 ~}$

これまでの研究として, WitheyらによるTEM内その場ナ ノインデンテーション ${ }^{8)}$ およびTEM内その場ナノピラー圧 縮試験 ${ }^{9)}$ を用いた検討がある。これらの検討から、ゴムメ タルの塑性変形が理想強度レベルで生じることが直接観察さ れ, その変形の際に特定の局所領域において連続的な結晶回 転が生じることが認められたが, 恋形時の転位の直接観察は されていない。これとは別に変形時の転位の直接観察がされ た報告例 ${ }^{10) \sim 12)}$ もあるが，これらの報告例においては，ゴ

\footnotetext{
${ }^{1}$ 茨城大学大学院（日立市）〔現在：株式会社日立パワーソリューションズ〕 Graduate School, Ibaraki University (Hitachi-shi, Ibaraki)〔Present: Hitachi Power Solutions Co.,Ltd.]

2 茨城大学（†316-8511 茨城県日立市中成沢町 4-12-1） Ibaraki University (4-12-1 Nakanarusawa, Hitachi-shi, Ibaraki 316-8511)

3 物質・材料研究機構（つくば市）〔現在：高周波熱錬株式会社〕 National Institute of Materials Science (Tsukuba-shi, Ibaraki)〔Present: Neturen Co., Ltd.]

4 物質・材料研究機構（つくば市） National Institute of Materials Science (Tsukuba-shi, Ibaraki)

5 九州大学 (福岡市) Kyushu University (Fukuoka-shi, Fukuoka)

* 責任著者E-mail: shigeru.kuramoto.11@vc.ibaraki.ac.jp
} 
ムメタルとは合金組成が異なる試料を用いていたり，平均組 成がゴムメタルと同一でも，大きなマクロ偏析を有する試料 を用いている可能性がある。 $\mathrm{Ti}-\mathrm{Nb}$ 系合金においては，わず かな組成の違いがベー夕相の安定性を変化させ，変形機構や マルテンサイト変態温度に大きな影響を与えることが報告さ れており ${ }^{13) \sim 17)}$ ，均一な合金組成を有する試料を用いて評価 することが重要である。一方，比較的高温かつ長時間の焼結 条件とした粉末治金プロセスを適用することにより，マクロ 偏析の問題を回避したゴムメタルを試料とした検討において も, 転位機構による変形が示唆される実験結果も報告されて いる ${ }^{18), 19)}$

本研究では，ゴムメタルおよび同じ bcc 構造を有する $\beta$ 型 チタン合金である $\beta \mathrm{III} （ \mathrm{Ti}-11.5 \mathrm{Mo}-6 \mathrm{Zr}-4.5 \mathrm{Sn})$ 合金を対象と して，変形をナノスケールでリアルタイムに観察をすること ができる TEM内その場圧縮試験を行い，転位の挙動や相変 態等の観点からゴムメタルの塑性変形機構を調査した。な お，一般的に使用されるゴムメタルは加工材であるが，本研 究ではゴムメタルの基本的な塑性変形機構を明らかにするた め，溶体化処理材に焦点を当てて研究を行った。

\section{2. 実 験方法}

ゴムメタル $(\mathrm{Ti}-35.9 \mathrm{Nb}-2.04 \mathrm{Ta}-2.74 \mathrm{Zr}-0.33 \mathrm{O}(\mathrm{mass} \%))$ と $\beta \mathrm{III}$ 合金 $(\mathrm{Ti}-11.5 \mathrm{Mo}-6 \mathrm{Zr}-4.5 \mathrm{Sn}(\operatorname{mass} \%))$ に溶体化処理 $\left(900^{\circ} \mathrm{C}\right.$, $30 \mathrm{~min}$ ，水焼き入れ）を施した。これらの試料の bcc 相の安定 性の指標となるMo当量は，それぞれ7,9であり，ゴムメ夕ル の方が若干 bcc 相の安定性が低い。鍛造方向と垂直な面を湿式 研磨（\#80～\#2000）および電解研磨により鏡面とし，TSL社製 OIM と JEOL 社製 JSM-7000F（電界放出型走査電子顕微鏡（FE$\mathrm{SEM})$ ）を用いて方位解析を行った。

本研究においては，まずナノインデンテーションを用い て, ゴムメタル溶体化処理材の変形挙動に及ぼす負荷速度と 結晶方位の影響を調査した。EBSDを行った試料に対して, ナノインデンテーションを行った。ナノインデンテーション はHysitron社製TI 950 TriboIndenterを使用し，室温にて荷重 制御によりインデントを行った。測定面は $\{111\}$ 面および $\{100\}$ 面とし，1つの結晶粒内で各条件最低 10 点以上インデ ントを行った。

TEM内その場圧縮試験に関しては，JEOL社製FIB加工装 置（JIB-4000やJEM-9320FIB）を用いて，圧縮面が（001）, 圧縮方向が $[00 \overline{1}]$ ，になるような，厚さ $100 \mathrm{~nm}$ 程度のピラー を作製した。その後，作製したピラーに対して，TEM内そ
の場圧縮試験を変位制御により行った。圧縮試験はJEOL社 製 JEM-2010F（電解放射型透過電子顕微鏡 (FE-TEM)）内 でHysitron社製 PI 95 TEM PicoIndenterを使用した。圧縮試験 後, 上記の FE-TEMや, JEOL社製JEM-2010（透過型電子顕 微鏡 $(\mathrm{TEM})$ ) を用いて, 圧縮試験後のピラーの観察を行っ た。Table 1 に各ピラーの試験条件を示す。

\section{3. 実 験 結 果}

\section{1 ナノインデンテーション}

ナノインデンテーションにより，ゴムメタル溶体化処理材 の $\{111\}$ 面に2種類の荷重負荷速度（ $5 \mu \mathrm{N} / \mathrm{s}, 500 \mu \mathrm{N} / \mathrm{s})$ にて インデントした際の荷重-変位曲線を Fig. 1 に示す。ナノイ ンデンテーションでは, 負荷過程において, 約 $150 \mu \mathrm{N}$ 付近 および約 $300 \mu \mathrm{N}$ 付近で変位バースト（pop-in）が生じた。ナ ノインデンテーションでは, 試験を荷重制御で行っており, このような変位バーストは, 変形抵抗の急激な低下を表して いる。pop-in 以降の塑性変形域では変形速度依存性が確認さ れ，負荷速度が小さい場合に，同一の荷重に対する梁さがよ り梁くなる傾向が見られた。ナノインデンテーションを用い て，ゴムメタル溶体化処理材の変形挙動に及ぼす負荷速度と 結晶方位の影響を調査した結果を Fig. 2 に示す。 $\{111\}$ 面お よび $\{100\}$ 面に関して，それぞれ2つの結晶粒で複数回の 測定を行った結果をエラーバーとともに示す。大きい負荷速 度でインデントした場合, 小さい負荷速度でインデントした 場合よりもナノ硬さの值が大きくなっている傾向も認められ

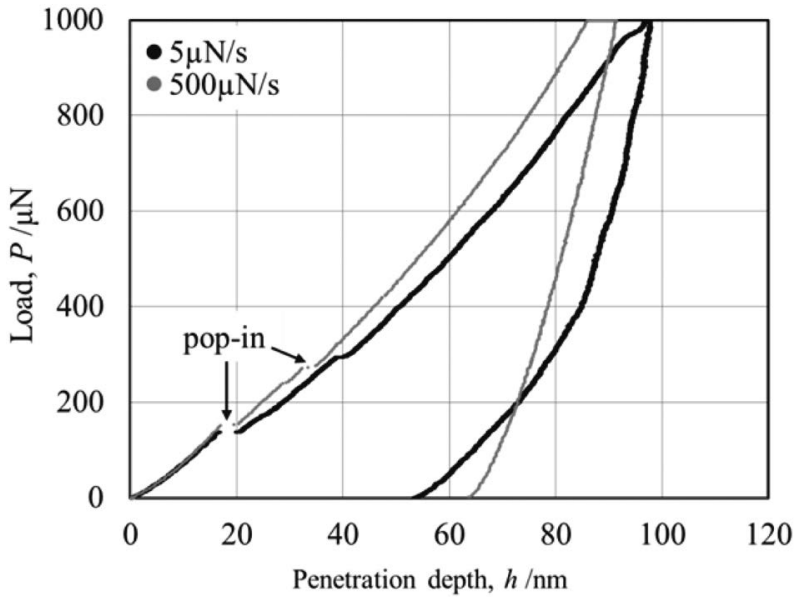

Fig. 1 Load-displacement curves during nanoindentation in solution-treated Gum Metal.

Table 1 Conditions of in-situ TEM compression test.

\begin{tabular}{|c|c|c|c|c|c|}
\hline & $\begin{array}{c}\text { Gum Metal } \\
\text { Pillar } 1\end{array}$ & $\begin{array}{c}\text { Gum Metal } \\
\text { Pillar } 2\end{array}$ & $\begin{array}{c}\text { Gum Metal } \\
\text { Pillar } 3\end{array}$ & $\begin{array}{c}\beta \text { III alloy } \\
\text { Pillar } 4\end{array}$ & $\begin{array}{c}\beta \text { III alloy } \\
\text { Pillar } 5\end{array}$ \\
\hline Pillar height [nm] & 780 & 400 & 1400 & 550 & 620 \\
\hline Max displacement [nm] & 200 & 200 & 500 & 200 & 250 \\
\hline Loading rate $[\mathrm{nm} / \mathrm{s}]$ & 1 & 1 & 1 & 1 & 1.25 \\
\hline Unloading rate $(0-20 \mathrm{~s})[\mathrm{nm} / \mathrm{s}]$ & 2 & 2 & 5 & 2 & 2.5 \\
\hline Unloading rate $(20-30 \mathrm{~s})[\mathrm{nm} / \mathrm{s}]$ & 16 & 16 & 40 & 16 & 20 \\
\hline Compression direction & [001] & [001] & [001] & [001] & [001] \\
\hline Observation plane & $(100)$ & (110) & $(100)$ & (110) & (110) \\
\hline Observation mode & Bright field & Diffraction & Bright field & Bright field & Diffraction \\
\hline
\end{tabular}




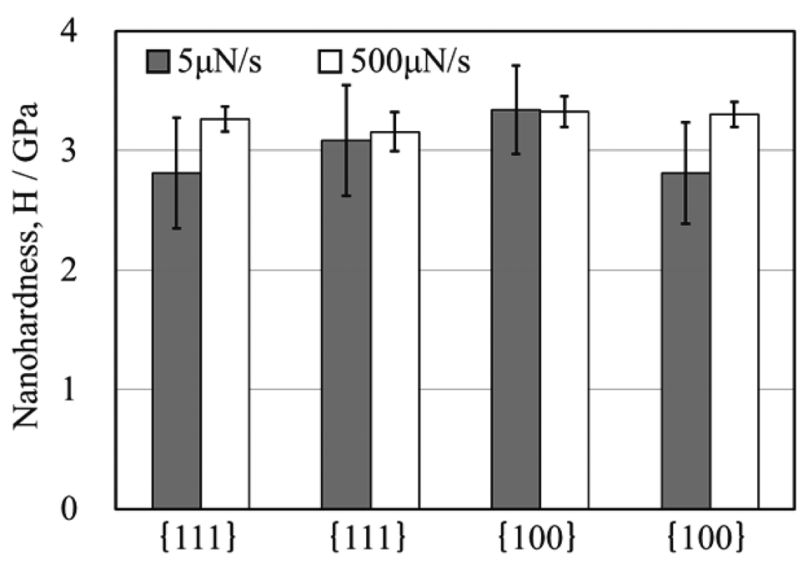

Fig. 2 Effect of deformation rate on nanohardness for four grains with surface orientation of $\{111\}$ or $\{100\}$ in solution-treated Gum Metal.

る。これは, ゴムメタル溶体化処理材の塑性変形が何らかの 熱活性化過程に支配されていることを示唆しているが，負荷 速度が小さい場合は測定データのばらつきが大きく，これら のデータから変形機構を推測することは困難である。本研究 ではこの現象についてこれ以上の検討は行わないが, 今後検 証の必要がある。なお, 測定面方位の違いはナノ硬さには大 きな影響を及ぼしていないことがわかる。Fig. 1に示される 通り，ゴムメタルにおいて明瞭な pop-inが観察されることか ら, ゴムメタル溶体化処理材においては転位の生成や増殖が pop-inの発生に寄与している可能性も考えられ, これを以下 のTEM内その場観察により検討する。

\section{2 公称応力-変位曲線}

TEM 内その場圧縮試験によって得られたゴムメタル溶体 化処理材（ピラー1,2）の公称応力-変位曲線を Fig. 3 (a) に, $\beta \mathrm{III}$ 合金溶体化処理材（ピラー4,5）の公称応力-変位曲線 をFig. 3(b) に示す。ゴムメタルのピラー3に関しては, 他 のピラーと比較して非常に小さい応力レベルで変形が生じ, 試験後の形状観察から圧縮变形が適切に行われていなかった ため,ここでは示していない。ただし，ピラー 3 は特殊な変 形挙動を示したため, 考察の項でそれに関して記述する。

ピラー 1,2 は, 圧子の押し込み深さが約 $70 \mathrm{~nm}$ になると, 公称応力-変位曲線の傾きが緩やかになることから, ここで 変形機構が弾性変形から塑性変形に移行したと考えられる。 さらに, 塑性変形が進行していくにつれ, 圧縮応力が徐々に 増加していることがわかる。これは，加工硬化の影響である と考えられる。塑性変形開始応力は約 $1.4 \sim 1.8 \mathrm{GPa}$, 塑性変 形が開始する前の弾性変形量は約 10\%であり, Witheyらの 結果 ${ }^{9)}$ とほほ同等の值となっている。このときピラーに発 生する最大せん断応力は圧縮応力の約 0.5 倍として概算する と, $\quad 0.7 \sim 0.9 \mathrm{GPa}$ である。ゴムメタルの理想せん断強度は約 $1.8 \mathrm{GPa}$ であり, 一般的に平均応力の 3 倍程度の応力集中が試 料内に発生することを考慮すると, かなり大きなせん断応力 レベルで塑性変形が開始していることを確認できる。なお, ゴムメタル溶体化処理材ではナノインデンテーションで見ら れたpop-inに対応する現象は生じない。このことから, 今回 のゴムメタル溶体化処理材の変形条件においては急激な転位 の生成や増殖が起こりにくいものと考えられる。

一方, Fig. $3(\mathrm{~b})$ に示した $\beta \mathrm{III}$ 合金溶体化処理材の公称応
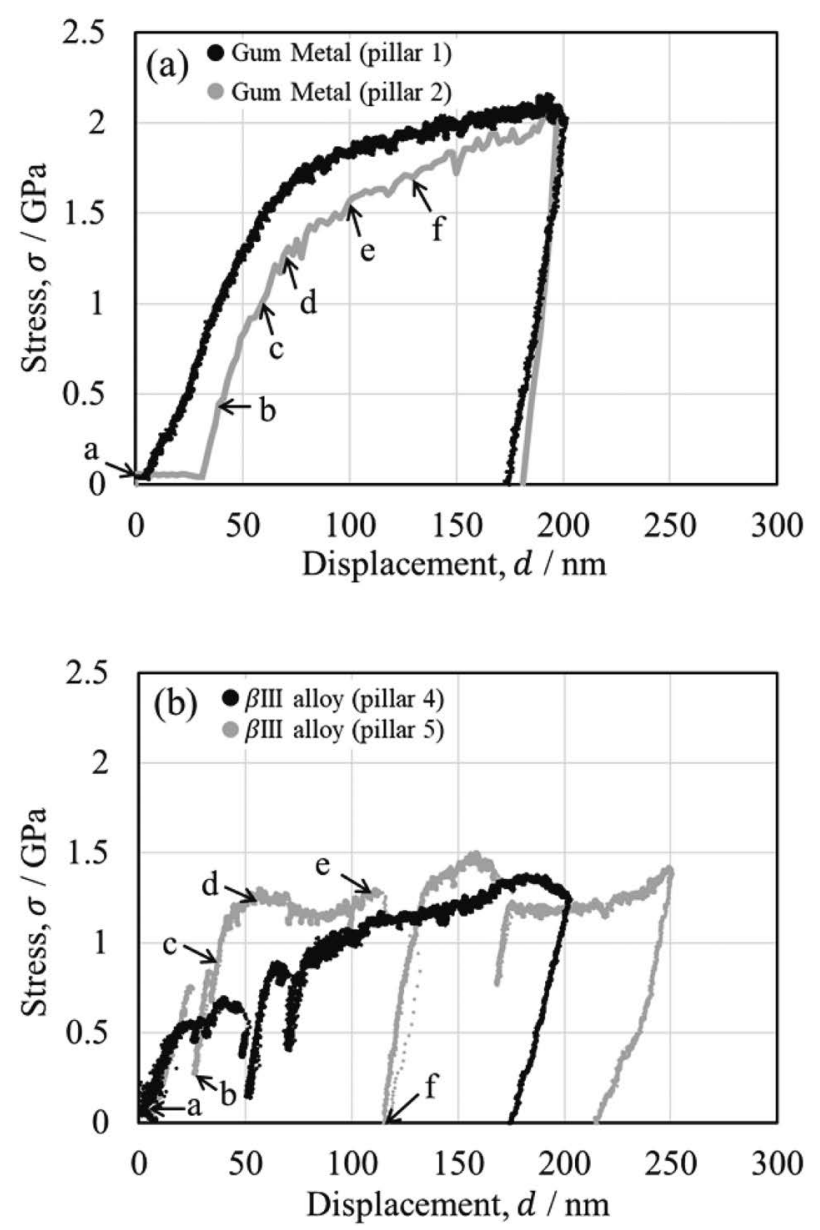

Fig. 3 Stress-displacement curves during in-situ compression tests. (a) Results of Gum Metal. (b) Results of $\beta$ III alloy.

力-変位曲線からは, 応力が急激に低下し, データが不連続 になっている現象が多数見られる。この現象はpop-inに対応 するものであり, 転位の急激な生成や増殖による塑性変形の 発現を示唆する。なお, $\beta$ III 合金の変形応力はゴムメタルに 比べて低い值を示すことも明らかである。

Fig. 3 の結果からは, $\beta$ III 合金溶体化処理材においては, 転位の生成や増殖に伴い塑性変形が進行していくことが予想 される。一方, ゴムメタル溶体化処理材では pop-inが生じな かったことから, 急激な転位の生成や増殖が起こりにくいと 予想される。

\section{3 明視野像モードでの観察結果}

Fig. 4 に圧縮試験中のゴムメタル溶体化処理材（ピラー 1） の明視野像を示す。Fig. 4(a) に矢印で示した線状のコント ラストは, 圧縮試験前に観察位置をずらしたところ, コント ラスト形状が変わったことから, 転位ではなく, ベンドコン ターであると考えられる。圧縮中に転位の明瞭な線状のコン トラストは観察されなかったが, 最初にFig. 4(b) の丸で囲 んだ領域で変形が集中し, この領域で数十 $\mathrm{nm}$ 程度のコント ラストの遷移が観察された。これが転位の運動に対応したコ ントラスト変化である可能性もあるが, ここで観察された転 位のようなコントラストは, 過去にWitheyらによって観察 された転位 ${ }^{8)}$ と比較すると, 約 $1 / 10$ 程度の非常に小さいこ とが確認された。このようなコントラスト変化は, 試験開始 直後に丸で囲んだ先端部で変形し, さらに圧縮をしていくこ 

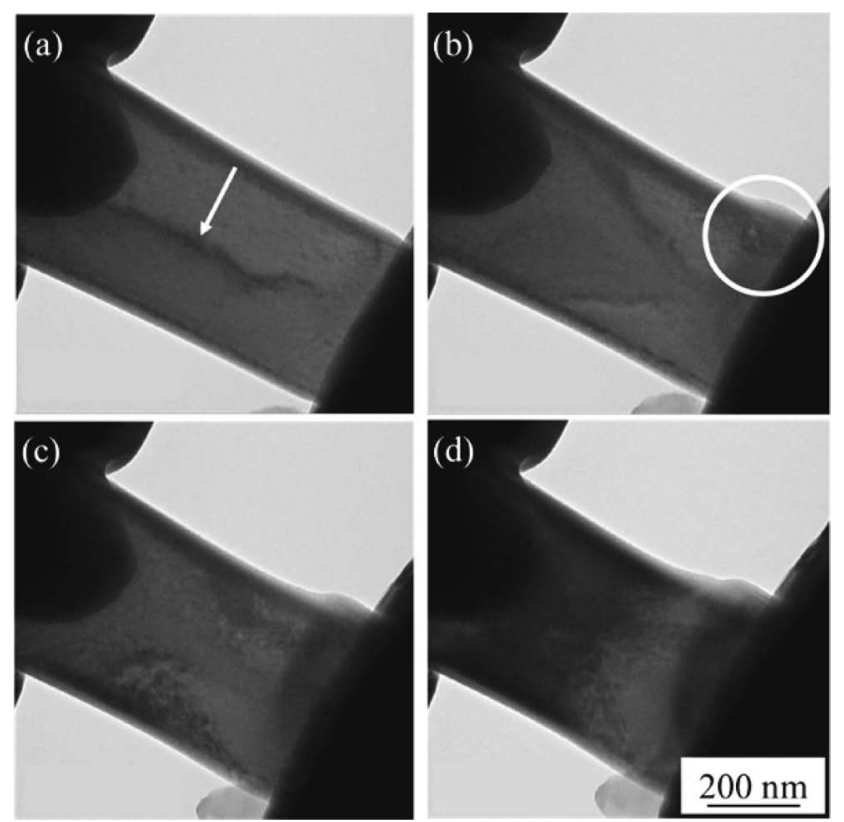

Fig. 4 Bright field images of Gum Metal (pillar 1) during compression. (a) $d$ (Displacement of indenter) $=50 \mathrm{~nm}$. (b) $d=100 \mathrm{~nm}$. (c) $d=150 \mathrm{~nm}$. (d) $d=200 \mathrm{~nm}$.
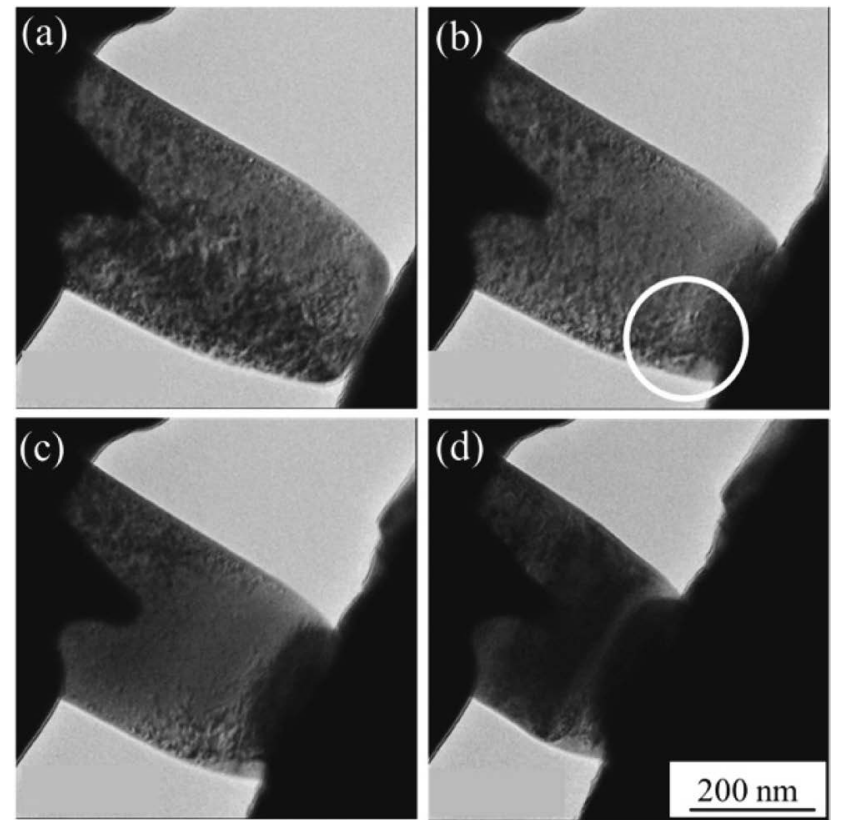

Fig. 5 Bright field images of $\beta$ III alloy (pillar 4) during compression. (a) $d=0 \mathrm{~nm}$. (b) $d=50 \mathrm{~nm}$. (c) $d=100 \mathrm{~nm}$. (d) $d=200 \mathrm{~nm}$.

とにより，ピラー中心部や根元部にも生じる様子が観察され たが，その詳細については本研究の範囲内で明らかにするこ とができなかった。

Fig. 5 に圧縮試験中の $\beta$ III 合金溶体化処理材（ピラー4）の 明視野像を示す。Fig. 5(a) でピラー全体に黒いコントラス トが観察された。このコントラストが何によるものであるか は明らかにできていないが，おそらくFIB加工によるピラー へのダメージや $\omega$ 相によるコントラストだと思われる。 $\beta \mathrm{III}$ 合金溶体化処理材においてもゴムメタル溶体化処理材と同様 に，試験開始直後にピラー先端部で変形し，さらに圧縮をし ていくことにより，ピラー中心部や根元部にも変形が生じる
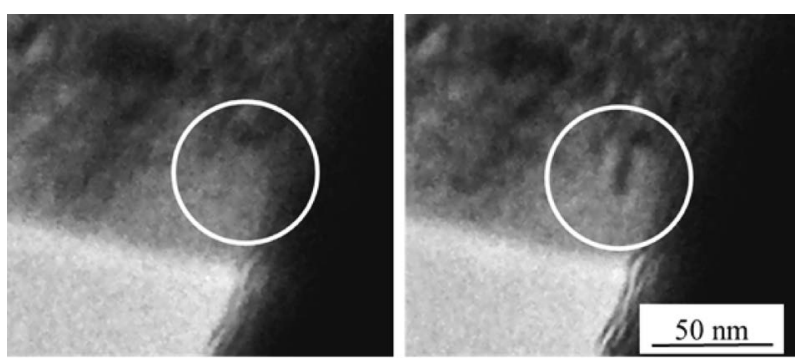

Fig. 6 Bright field images of top of pillar of $\beta$ III alloy (pillar 4) during compression. (a) Before a line like dislocation is observed. (b) After a line like dislocation was observed.

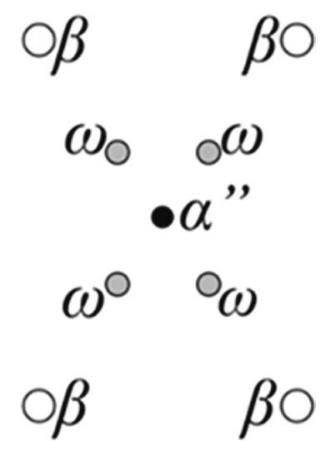

Fig. 7 Example of diffraction pattern when electron beam is incident on $\beta$-type titanium alloy from $\langle 110\rangle$.

(a)

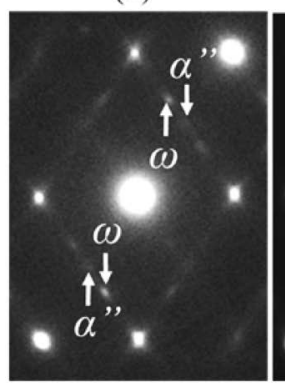

(d)

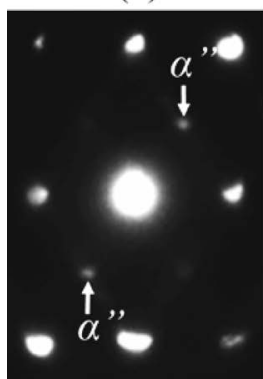

Fig. 8 Diffraction pattern of Gum Metal (pillar 2) during compression.

様子が観察された。転位の明瞭なコントラストの観察は困難 であったが, Fig. 5(b) の丸で囲んだ領域で転位の運動と思 われるコントラストの遷移が観察された。Fig. 6 に圧縮中の $\beta \mathrm{III}$ 合金溶体化処理材 (ピラー4) の先端部の明視野像を示 す。丸で囲んだ領域において，転位と思われるコントラスト が, Fig. 6(a) では観察されていないが, Fig. 6(b) では観察 された。 

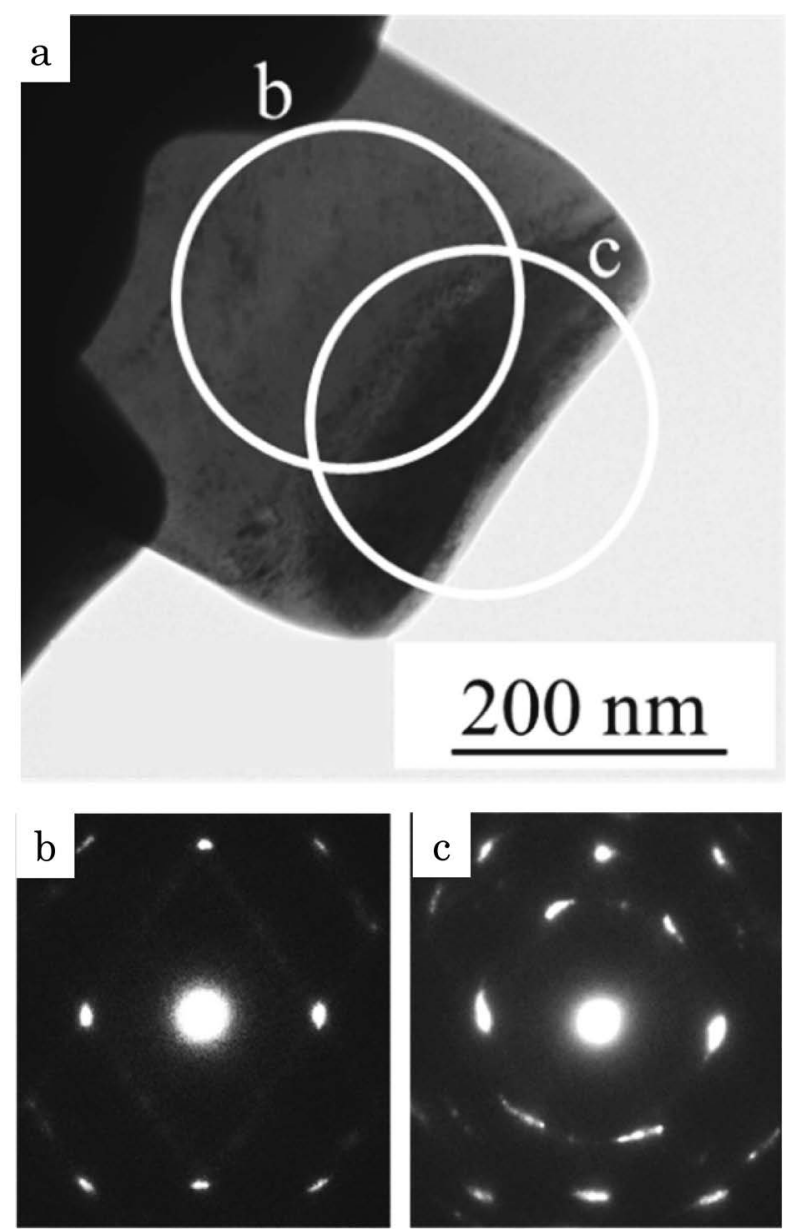

Fig. 9 Bright field image and diffraction pattern of Gum Metal (pillar 2) after compression test.

\section{4 電子線回折モードでの観察結果}

Fig. 7 に， $\beta$ 型チタン合金に電子線を〈110〉功入射した ときの電子線回折図形における各相の回折スポットの位置を 示す。本研究では, 電子線の入射方向と圧縮軸が垂直となっ ており, 変形に伴う相変化を電子線回折図形の変化として捉 えることが可能となる。

Fig. 8 に圧縮中のゴムメタル溶体化処理材（ピラー2）の 電子線回折図形を示す。Fig. 8 (a)〜 (f) はFig. 3 中に矢印で 示した箇所にそれぞれ対応している。圧縮前のFig. 8(a) で は，母相である $\beta$ 相のほかに $\omega$ 相からの回折と応力誘起マル テンサイト相である $\alpha^{\prime \prime}$ 相からの回折が見られ，回折強度は $\alpha^{\prime \prime}$ 相よりも $\omega$ 相からの回折が強い。圧縮試験前から $\alpha^{\prime \prime}$ 相お よび $\omega$ 相が観察された理由としては，湿式研磨による加工層 が電解研磨で除去できなかった可能性やFIBによるダメージ の影響等も考えられる。圧縮変形が進行していくと徐々に $\omega$ 相からの回折が弱くなる一方で， $\alpha^{\prime \prime}$ 相からの回折が強く なることがFig. 8(b)〜 (d) から観察された。これは, 変形 に伴い, $\beta$ 相から $\alpha$ 相への応力誘起マルテンサイト変態が生 じ， $\omega$ 相は $\beta$ 相に逆変態した結果であると考えられる。した がって，Fig. 4(c)，（d）で見られる黒色のまだら模様のコン トラストは, $\alpha^{\prime \prime}$ 相の可能性もある。この点については, 今 後さらに様々な回折条件でのその場変形観察実験を実施する ことにより，明らかにすることが可能であろう。また，Fig. $8(\mathrm{e}),(\mathrm{f})$ で, 回折強度が全体的に徐々に弱くなっていくこ (a)

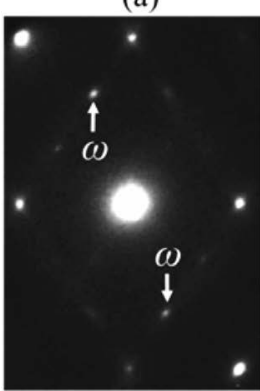

(d)

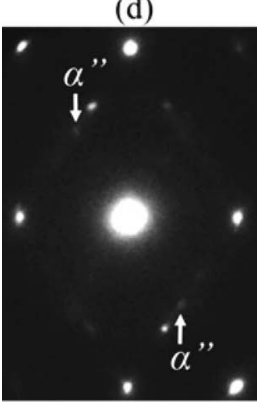

Fig. 10 Diffraction pattern of $\beta$ III alloy (pillar 5) during compression.
とが観察されたが, これは, 変形の進行により入射条件が変 化したこと，ピラー先端部が観察位置となるように制限視野 絞りを入れて観察を行ったため, 時間の経過に伴い圧子が制 限視野内に侵入したこと，などが原因として考えられる。

Fig. 9 に圧縮試験終了後のゴムメタル溶体化処理材（ピ ラー2）の明視野像と電子線回折図形を示す。Fig. 9(a)の試 験片中央部（b）と先端部（c）の電子線回折図形をそれぞれ Fig. 9(b)，（c）に示す。Fig. 9(b) から，試験後には $\beta$ 相から の回折が主に認められ，入射方向を軸とした結晶回転が若干 生じていることがわかる。またFig. 9(c) から, ピラー先端 部での塑性変形の集中に対応して大きな結晶回転が観察され た。このような傾向は, ピラー2だけでなく, 本研究で用い たすべてのピラーで見られる傾向であった。

Fig. 10 に圧縮中の $\beta$ III 合金溶体化処理材（ピラー5）の電 子線回折図形を示す。Fig. $10(\mathrm{a}) \sim(\mathrm{f})$ はFig. 3 中に矢印で示 した箇所にそれぞれ対応している。圧縮前のFig. 10(a)では, 母相である $\beta$ 相のほかに $\omega$ 相からの回折が観察された。Fig. 10 (a)〜 (c) まで, 電子線回折像はほとんど変わらないが, 降伏直前の Fig. 10 (d) では， $\alpha$ 相からの回折が観察された。 この結果から, $\beta \mathrm{III}$ 合金溶体化処理材もゴムメタル溶体化処 理材と同様に, $\beta$ 相から $\alpha^{\prime \prime}$ 相への応力誘起マルテンサイト変 態が生じたと考えられる。 $\alpha^{\prime \prime}$ 相からの回折は微弱ながら Fig. 10 (e) まで続くが, pop-in直後の Fig. 10（f）では消滅してい る。これは, pop-in時に $\alpha^{\prime \prime}$ 相から $\beta$ 相へ逆変態が生じたこと や，結晶回転が生じたことにより電子線の入射方向に対して $\alpha^{\prime \prime}$ 相が回折条件を満たさなくなったことなどが考えられる。

\section{4. 考察}

本研究では, bcc構造を有するゴムメタルおよび $\beta$ III 合金 の溶体化処理材を対象として, TEM内その場圧縮試験を行 い,これらの合金の塑性変形挙動を調査した。事前にゴムメ タルのナノインデンテーションを用いた変形挙動の調査を行 い,その際に認められた pop-in との対応にも着目しながら， 
その場圧縮試験を実施し, 変形中の転位の運動や相変態挙動 の調査を行った。その結果，転位の運動に関しては明瞭な実 験的証拠を得ることができなかったが，変形中の相変態に関 しては, 電子線回折の結果からある程度の情報を得ることが できた。ここでは, pop-inに関連する変位バースト現象, 変 形中の転位の運動, 相変態の塑性変形への寄与に関して考察 を行う。

まず, pop-inに関して変形条件や試料による発生挙動の違 いを考える。Fig. 1に見られるように，ゴムメタルのナノイ ンデンテーションにおいては, 明瞭な pop-inが認められた。 ここに示した結果は $\{111\}$ 面に関するものであるが， $\{100\}$ 面に関しても，発生する荷重レベルは異なるもののpop-inの 発生が認められた。このような pop-inは, 具体的な変形機構 を特定することはできないが，この発生とともに大規模な塑 性変形が生じたことを示唆するものである。また, pop-in 発 生後に荷重-変位関係に速度依存性が認められることから, pop-in 発生前は弾性変形のみが生じ, その後は塑性変形が生 じていることは間違いないと考える。しかし, その場変形観 察の結果からは、ゴムメタルの応力-変位曲線上にpop-in は 生じず (Fig. 3(a)), 明視野像観察のビデオにも大規模な塑 性変形開始に伴う現象を認めることはできなかった。これ は, Witheyらの過去の報告結果 ${ }^{9)}$ とも一致する。一方, $\beta \mathrm{III}$ 合金の応力-変位曲線上には pop-in と類似の現象と思われる 応力の急激な低下が明瞭に認められた（Fig. 3(b))。本研究 において， $\beta$ III合金のナノインデンテーションは実施してい ないが, Fig. 3(b) の結果から, ゴムメタルと同様のナノイ ンデンテーション試験を実施すれば, pop-inが生じる可能性 が高い。

TEM内その場圧縮試験では, 試験を変位制御で行ってい るため, pop-inは急激な応力の低下として発現するが，ナノ インデンテーションでは, 試験を荷重制御で行っているた め, 変位バーストとして発現し, どちらの場合も変形抵抗の 急激な低下を表している。ゴムメタルと $\beta \mathrm{III}$ 合金の応力-変 位曲線を比較すると，ゴムメタルの方が比較的大きな加工硬 化を示しており，これが変形の局所化を抑制し， pop-inの発 生を阻害したことも考えられる。また, ナノインデンテー ションにおいては, 転位密度の低い領域に転位を発生させる ために大きな応力が必要となり, 結果としてある臨界応力 に達したときにpop-inが生じることが考えられる。これに対 し， ピラーの変形では，FIBによるピラー形状への加工の際 に導入された転位やその他の欠陥が存在することにより，そ れらが低応力で塑性変形の開始を可能とするために, 結果と して塑性変形が徐々に生じて pop-inが生じにくかった可能性 も考えられる。しかし，ピラーの変形においてゴムメタルで は観察されなかったpop-inが $\beta$ III 合金において観察されたこ とは，そのような試験条件の違いだけでなく，合金組成の違 いの方が大きな影響を有していることを示唆している。

次に, ピラーの変形中に観察された転位のようなコントラ ストについて考察する。TEM内その場圧縮試験は, 変形中 の転位の運動を直接観察できる非常に有効な実験手法であ り，これまでにbcc 結晶構造を有する鉄鋼材料において，塑 性変形に伴う転位の運動を明瞭に捉えることに成功してき た ${ }^{20) \sim 22)}$ 。しかしながら, 本研究においてはわずかに $\beta \mathrm{III}$ 合 金中で転位のようなコントラストが認められただけであっ
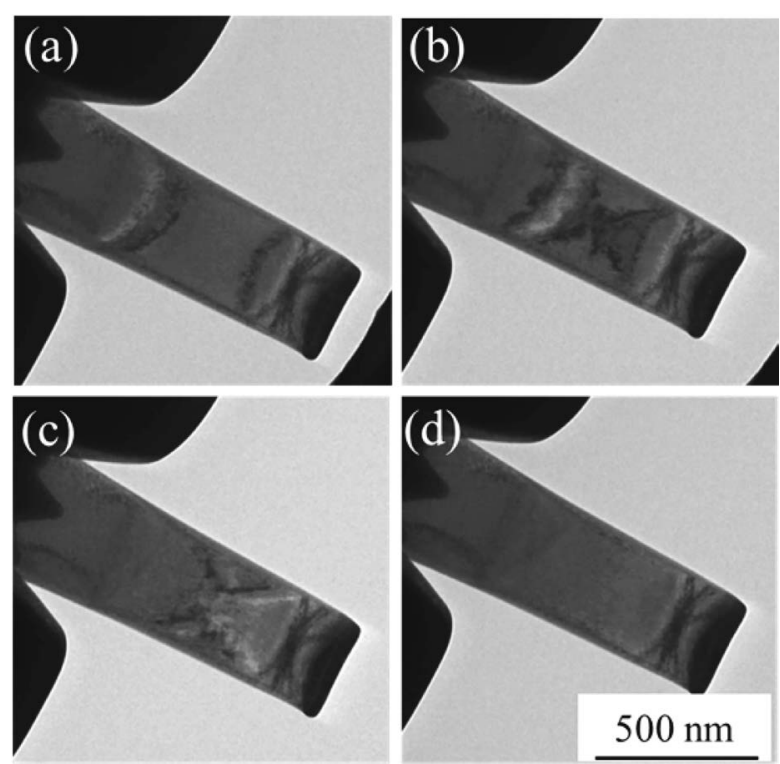

Fig. 11 Bright field images of pillar 3. (a) immediately after, (b) $4 \mathrm{~s}$ after, (c) $15 \mathrm{~s}$ after and (d) $30 \mathrm{~s}$ after the unloading.
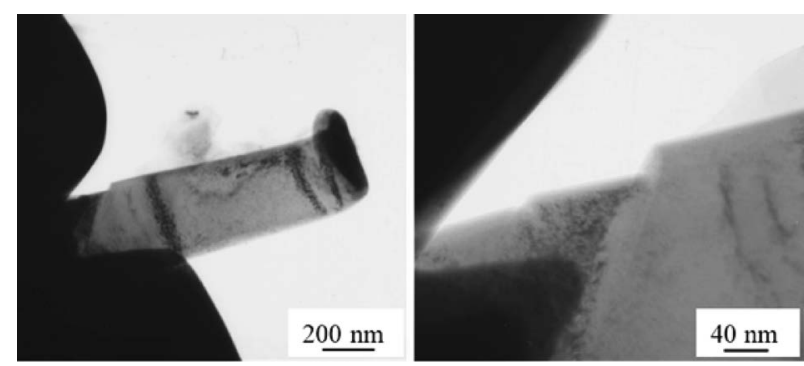

Fig. 12 Bright field images of Gum Metal (pillar 3) after compression test. (a) overall view of the pillar. (b) root of the pillar.

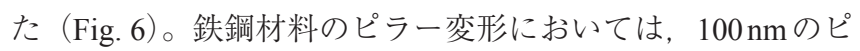
ラーの幅全体に広がり, 移動する転位が明瞭に観察されてい る。また, ナノインデンテーションにより塑性変形を与えた ゴムメタルにおいても，100〜200 nmの範囲にわたり明瞭な コントラストを有する転位の存在が確認されている。当初, 本研究においても, その場変形観察によって同様の転位のコ ントラストを観察することを予想して実験を進めたが, Fig. 4, Fig. 5 に示す通り，ゴムメタルと $\beta \mathrm{III}$ 合金の双方において， 予想とは異なり明瞭な転位のコントラストを観察することが 困難であった。また，圧縮変形後のピラーを，2軸傾斜ホル ダーで回折条件を変化させながら観察してみたが, それでも 転位の明瞭なコントラストは観察されなかった。

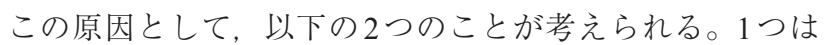
今回の試料において, 転位機構以外の塑性変形機構が働いた ことであり，もう1つは転位機構が働いていたが, 観察が困 難であったことである。前者に関しては, ピラー変形中の 強度レベルと理想強度との関係を確認する必要がある。Fig. 3 においてゴムメタルのピラーに発生するマクロな最大せん 断応力は $0.7 \sim 0.9 \mathrm{GPa}$ であり, 理想せん断強度の $50 \%$ 程度の 応力下で変形が生じていることになる。これは応力集中係数 が2程度まで高まることにより, 局所的な変形応力が理想強 度に達して, 転位の運動の助けを借りることなく塑性変形が 
生じる可能性を示唆する。また，変形に伴い $\beta$ 相から $\alpha$ 相へ の応力誘起マルテンサイト変態が生じており, これが塑性変 形に寄与している可能性もある。後者に関しては，圧縮変形 中に局所的な結晶回転が生じて，広範囲にわたって同一の回 折条件とならなかったことが，転位の観察を困難にした可能 性がある。Fig. 9 に示されている通り，変形後のピラーには 結晶格子連続的な方位回転が生じており，試料の場所により 回折条件が変化していることがわかる。本研究では局所的な 方位分布の定量化は実施していないが，このような方位回転 が，ピラー全体に広がる転位の観察を困難にした可能性はあ る。今回用いた試料のヤング率が低いことが，このような試 験片での観察をより困難にした可能性もある。いずれにせ よ, 双方の試料において塑性変形は非常に小さな領域で生じ て局所的な結晶回転を伴っており，これがこれらの合金の変 形挙動の特徵であると言える。

最後に $\alpha^{\prime \prime}$ マルテンサイトの変形への寄与について考える。 Fig. 8, Fig. 10 に示される通り, 今回の試料においては, 変形 中に $\beta$ 相から $\alpha^{\prime \prime}$ 相への応力誘起マルテンサイト変態が生じ た。一般的に，このような塑性変形中のマルテンサイト変態 は，塑性変形に寄与することも考えられる。しかし，ゴムメ タルや $\beta$ III 合金においては，変態によって生じる格子ひずみ は小さく，変態自体が塑性変形に寄与する割合は小さいこと

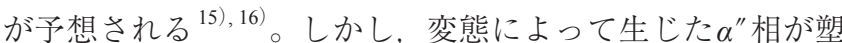
性変形を生じ，変形後に $\beta$ 相に逆変態するような可能性も否 定できない。 $\alpha^{\prime \prime}$ 相の塑性変形に関してはほとんど報告例が なく，今後の検討が必要であろう。ここで，相変態に関する 現象として，ピラー3において興味深い現象が観察されたの で，追記しておく。

Fig. 11 に除荷終了直後のゴムメタル溶体化処理材（ピ ラー3）の明視野像を示す。圧子がピラーから離れていて荷 重が負荷されていない状態にもかかわらず，回折コントラス トが30秒間に徐々に変化していく様子が観察された。この 現象は，圧縮応力が完全に除去された後に，30秒間変形が 継続していることから，その機構は特定することはできな いが，擬弾性変形を捉えた結果であると考えられる。この 擬弾性と関係する現象はゴムメタルのピラー 3 のみで観察さ れ，他のゴムメタルのピラーおよび $\beta \mathrm{III}$ 合金のピラーでは観 察されなかった。理由としては, ピラー 3 は他のピラーより も圧縮軸方向に長く，圧縮軸とピラーの長手軸のわずかなず れにより曲げ変形が生じやすく，ピラーの曲げに起因する回 折コントラストの遷移がより顕著に観察されたことが考えら れる。Fig. 12 に圧縮試験後のゴムメタル溶体化処理材（ピ ラー3）の明視野像を示す。ピラー先端部で大きく曲げ変形 が生じていることがわかる。また，ピラー根元部では過去に ゴムメタル加工材で観察されているような断層が観察され た。これらの観察結果は, ピラー3においては先端と根元で 大きな曲げ変形が生じたことを意味し，除荷後に根元部分で ゆっくりと 30 秒間にわたって擬弾性変形が生じたことを示 唆している。しかし，観察された回折コントラストがピラー の曲げに起因したものであるのか，それとも相変態等のピ ラーの内部構造の変化に起因したものであるのか本研究では 明確にできていない。

著者らのこれまでの研究結果 ${ }^{1) ~ 7)}$ によれば，ゴムメタル

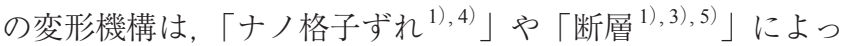

て特徵づけられる。断層は結晶粒内部での不均一せん断変形 であり，\{112\}〈111〉に沿って生じることもあれば，そこか らある程度の角度を成した結晶面に生じることもある。この 断層は，也ん断面の近傍に連続的な結晶回転を生じた厚さ 100〜200 nmの変形層を伴うことが特徵であり，Fig. 9 で観察 された結晶回転も，断層近傍の変形組織と類似している。な お，すべてのピラーで連続的な結晶回転のみが観察されたこ とから, このような変形挙動はゴムメタルに限ったものでは なく，今回使用した試料のような bcc 相の安定性をもつ $\beta$ チ タン合金に共通の特徵である可能性もある。一方，断層自体 はゴムメタルのピラー3においてのみ，根元部の応力集中の 大きい部分に観察されたため，断層に関してはゴムメタルに 特有の変形である可能性が高い。これらの点については, 本 研究の範囲内で明確に結論づけることは不可能であるが，今 後様々に試料形状や回折条件を変化させた実験を実施するこ とにより明らかにすることができると考える。

\section{5. 結言}

本研究では，ゴムメタル溶体化処理材の塑性変形機構を解 明するため，ゴムメタルと同じ bcc 構造を有する $\beta$ 型チタン 合金である $\beta \mathrm{III}$ 合金溶体化処理材を比較材として変形挙動を 検討した。ナノインデンテーションにおける塑性変形時に, ゴムメタル溶体化処理材は加工硬化や pop-in, 変形速度依存 性を示したことから，塑性変形に転位が寄与していることが 示唆された。そして，ゴムメタルと $\beta \mathrm{III}$ 合金変形のピラーを 作製し，ナノスケールでリアルタイムに観察をすることがで きる TEM内その場圧縮試験を行った。以下に得られた結果 を要約して示す。

（1）ゴムメタル溶体化処理材は，圧縮中に転位の明瞭な コントラストは観察されなかったが, 変形が集中している領 域では，転位の運動と思われるコントラストの変化が観察さ れた。 $\beta \mathrm{III}$ 溶体化処理材合金においても圧縮中に転位の明瞭 なコントラストは観察されなかったが，ゴムメタルとは異な り転位らしきコントラストを観察することができた。双方の 試料において塑性変形は非常に小さな領域で生じて局所的な 結晶回転を伴っており，これがこれらの合金の変形挙動の特 徵であると考えられる。

（2）ゴムメタル溶体化処理材は，変形が進むにつれて $\omega$ 相からの回折は徐々に弱くなり， $\alpha^{\prime \prime}$ 相からの回折が徐々に 強くなる。したがって，ゴムメタルの塑性変形を担うものは, 転位の運動だけではなく, $\beta$ 相から $\alpha^{\prime \prime}$ 相への応力誘起マルテ ンサイト変態も塑性変形を担う一因である可能性がある。類 似の挙動が $\beta$ III 合金溶体化処理材においても認められた。

（3）ゴムメタル溶体化処理材のうち, 試料長さの大きい ピラーは先端部および根元部で大きな曲げ変形を示し，除荷 後に擬弾性挙動を示した。

\section{謝 辞}

本研究は，文部科学省委託事業ナノテクノロジープラット フォーム課題として物質・材料研究機構微細構造解析プラッ トフォーム $(\mathrm{NMCP})$ の支援を受けて実施されたものである。 ここに記し，感謝申し上げます。

\section{参 考 文 献}

1) T. Saito, T. Furuta, J. H. Hwang, S. Kuramoto, K. Nishino, N. 
Suzuki, R. Chen, A. Yamada, K. Ito, Y. Seno, T. Nonaka, H. Ikehata, N. Nagasako, C. Iwamoto, Y. Ikuhara and T. Sakuma: Science, 300 (2003), 464-467.

2) 倉本 繁, 西野和彰, 斎藤 卓：軽金属, 55（2005），618-623.

3) S. Kuramoto, T. Furuta, J. H. Hwang, K. Nishino and T. Saito: Metall. Mater. Trans. A, 37A (2006), 657-662.

4) M. Y. Gutkin, T. Ishizaki, S. Kuramoto and I. A. Ovid'ko: Acta Mater., 54 (2006), 2489-2499.

5) M. Y. Gutkin, T. Ishizaki, S. Kuramoto, I. A. Ovid'ko and N. V. Skiba: Int. J. Plast., 24 (2008), 1333-1359.

6) 倉本 繁, 古田忠彦, 長迴尚之：軽金属, 62（2012）, 406-411.

7) T. Furuta, S. Kuramoto, J. W. Morrs Jr., N. Nagasako, E. Withey and D. C. Chrzan: Scr. Mater., 68 (2013), 767-772.

8) E. Withey, M. Jin, A. M. Minor, S. Kuramoto, D. C. Chrzan and J. W. Morris Jr.: Mater. Sci. Eng. A, 493 (2008), 26-32.

9) E. Withey, A. M. Minor, D. C. Chrzan, J. W. Morris Jr. and S. Kuramoto: Acta Mater., 58 (2010), 2652-2665.

10) Y. Yang, S. Q. Wu, G. P. Li, Y. L. Li, Y. F. Lu, K. Yang and P. Ge: Acta Mater., 58 (2010), 2778-2787.

11) M. Besse, P. Castany and T. Gloriant: Acta Mater., 59 (2011), 59825988.

12) P. Castany, M. Besse and T. Gloriant: Phys. Rev. B, 84 (2011),
020201.

13) J. H. Hwang, S. Kuramoto, T. Furuta, N. Nishino and T. Saito: J. Mater. Eng. Perform., 14 (2005), 747-754.

14）倉本 繁, 古田忠彦, ファンジョンハン, 西野和彰, 斎藤 卓 : 日本金属学会誌，69(2005)，953-961.

15) J. I. Kim, H. Y. Kim, H. Hosoda and S. Miyazaki: Mater. Trans., 46 (2005), 852-857.

16) H. Y. Kim, Y. Ikehara, J. I. Kim, H. Hosoda and S. Miyazaki: Acta Mater., 54 (2006), 2419-2429.

17) M. Tane, T. Nakano, S. Kuramoto, M. Hara, M. Niinomi, N. Takesue, T. Yano and H. Nakajima: Acta Mater., 59 (2011), 6975-6988.

18) Y. Kamimura, S. Katakura, K. Edagawa, S. Takeuchi, S. Kuramoto and T. Furuta: Mater. Trans., 57 (2016), 1526-1534.

19) R. P. Sankaran, V. B. Ozdol, C. Ophus, J. Kacher, C. Gammer, S. Govindjee, A. M. Minor and J. W. Morris Jr.: Acta Mater., 151 (2018), 334-346.

20) L. Zhang, T. Ohmura, K. Sekido, T. Hara, K. Nakajima and K. Tsuzaki: Scr. Mater., 67 (2012), 388-391.

21) L. Zhang, N. Sekido and T. Ohmura: Mater. Sci. Eng. A, 611 (2014), 188-193.

22) Y.-C. Hsieh, L. Zhang, T.-F. Chung, Y.-T. Tsai, J.-R. Yang, T. Ohmura and T. Suzuki: Scr. Mater., 125 (2016), 44-48. 